DOI https://doi.org/10.30525/978-9934-26-113-8-32

\title{
РОЛЬ НЕОРГАНІЧНИХ ФТОРИДІВ У ЛІКУВАННІ І ПРОФІЛАКТИЦІ КАРІЕСУ
}

\author{
Нікогосян Л. Р. \\ доктор медичних наук, професор, \\ завідувач кафедри фармачії \\ Одеський начіональний медичний університет
}

Анісімов В. Ю.

кандидат біологічних наук, доцент, декан факультету фармації

Одеський національний медичний університет

Корольов М. В.

асистент кафедри фармачіі

Одеський національний медичний університет

\section{Вербицький О. А.}

курсант

Одеський національний медичний університет

Бевза О. В.

курсант

Одеський національний медичний університет м. Одеса, Україна

На даний час широкого поширення набули такі топічні фторовмісні засоби, як зубні пасти, фторовмісні ополіскувачі, лаки, гелі, розчини для глибокого фторування та електрофорезу, з'являються принципово нові пристосування для пролонгованої місцевої дії фторидів на емаль (фторовмісні диски, фіксовані на зубах елементи тощо). Карієс профілактичний ефект місцевого застосування фторидів не викликає сумніву, проте досі тривають дискусії стосовно оптимальної концентрації фториду в даних засобах, оптимальних схем та кратності їх використання, проте навіть місцева фториста профілактика не може забезпечити повного контролю над каріозним процесом, що спонукало i спонукає до продовження досліджень в даній області [3]. 
Ефективна аплікаційна ремінералізуюча терапія за С.В. Боровським включає: використання $10 \%$ розчин кальцію глюконату і $2 \%$ розчин натрію фториду. Поверхню зубів очищають від зубного нальоту, висушують повітрям і накладають тампони, змочені $10 \%$ розчином кальцію глюконату на 15-20 хв, кожні 3 хв змінюючи тампон. Після цього накладають тампони з 2-4 \% розчином натрію фториду на 2-3 хв. Рекомендують дитині не пити і не їсти протягом 2 год (15-20 аплікацій на курс лікування, щодня чи через день) [1].

Ефективність місцевого застосування фторидів у вигляді полоскання залежить від їх хімічної структури, концентрації фтору і рН-середовища. Дітям 3-5 років призначають полоскання зубів 0,2 \% розчином натрію фториду один раз на два тижні. Курс лікування - 3-4 полоскання. Дія дітей 7-14 років використовують $2 \%$ розчин натрію фториду у вигляді ротових ванночок протягом 2 хв (7-10 процедур на курс лікування). Курс лікування повторюють 3-4 рази на рік [1].

Місцеве введення кальцію у тверді тканини зуба бажано сполучати 3 прийомом кальцію внутрішньо. Ремінералізуючу дію препаратів можна підвищити шляхом ретельного очищення і висушування твердих тканин зубів, їх обробки слабкими кислотами і ферментами, застосуванням насичених теплих розчинів ремінералізуючих засобів, а також уведенням їх шляхом вакуум-електрофорезу, ультразвуку, фонофорезу й ін.

Однак, аплікаційний метод забезпечує лише короткочасний вплив на емаль фторовмісних сполук, що відносно швидко вимиваються. Тому більш доцільно використовувати різні покриття і лаки як депо фтору [4].

Фторлак - комбінований препарат, до складу якого входять (3 розрахунку на 100 г) натрію фторид (5 г), бальзам ялицевий (40 г), шелак (10 г), хлороформ (12 г), спирт етиловий (24 г). У воді не розчиняється, $\mathrm{pH}-5,25$.

Плівка фторлаку довго утримується на поверхні зубів, що забезпечує пролонговане насичення іонами фтору емалі і дентину зубів. Препарат має антимікробну активність. Перед нанесенням фторлаку поверхню зубів - протирають ватним тампоном із перекисом водню, висушують повітрям. Потім за допомогою ватної кульки наносять його тонким шаром на поверхню зубів. Через 4-5 хв. препарат висихає. Після цього протягом 12-24 годин варто приймати рідку їжу і не чистити зуби. Рекомендується триразове покриття зубів фторлаком 3 інтервалом 1-2 дні. Покривають зуби фторлаком 3-4 рази на рік. Середня редукція приросту карієсу при застосуванні лаку складає 50 \% [2].

Фторовмісні та $\mathrm{Ca} / \mathrm{P}$-вмісні гелі наносяться на зуби за допомогою спеціальних пластмасових ложок для верхньої і нижньої щелепи й 
утримуються на поверхні протягом 15-20 хв. Середня редукція карієсу при їх застосуванні складає від 30 до 50 \%. Фірма «Владміва» здійснює випуск гелю, що містить Са і Р (БелагельСа/Р) та препарат «Глуфторед», в якому молекули фтору в ньому менше за 1 мікрон. Це дає змогу підвищувати ефективність профілактики, цей метод $є$ досить ефективним методом глибокого фторування [5].

Ще більш виражений тривалий ремінералізуючий ефект спостерігається при втиранні за допомогою бормашини стоматологічних лікувальних дисків (віск-парафінові композиції) «Фторгліфоскаль», «Піростронат» тривалість процедури 3-5 хв., кількість процедур 5-10.

Нагнітання лікарської речовини за допомогою бормашини сприяє максимальному і найбільш глибокому ії проникненню з утворенням на поверхні зуба плівки, з якої діюча речовина витрачається протягом 2-х год [4].

Більш ефективний засіб профілактики карієсу - амінофториди (органічні сполуки фтору). Ці сполуки дифундують всередину емалі. У формі цих сполук фтор довше затримується на поверхні емалі й інтенсивніше реагує з гідроксоапатитом емалі. Препарати амінофторидів гальмують утворення зубної бляшки, підвищують стійкість емалі до кислот [5].

При ентеральному і парентеральному введенні фтор впливає на мінеральний і білковий обмін в організмі в цілому й у тканинах зубів. Однак, варто пам'ятати, що фтор це протоплазматична отрута, що гальмує процеси обміну в тканинах. Хронічне отруєння фтором виявляється різними симптомами при концентрації його у воді більше 10 мг/л. Сполуки фтору надходять в організм із водою і їжею у вигляді фторидів. Добова потреба в них для дітей різного віку складає: 1 рік 0,7 мг, 2 роки - 0,8 мг, до 4 років - 1 мГ, до 10 років - 1,3 мг, після 10 років $-1,5$ мг [3].

Для загальної профілактики фтор призначають у вигляді таблеток натрію фториду, фторованого молока, кухарської солі чи питної води. Середня концентрація фтору в штучно фторованій воді в умовах помірного клімату має: складати 0,8-1,2 мг/л. Як джерело фтору використовують і природні мінеральні води з високим його вмістом [2].

При недостатній концентрації фтору в питній воді рекомендується призначення препаратів фтору. Необхідна добова доза препарату встановлюється залежно від віку дитини і вмісту фтору в питній воді. Якщо з їжею дитина одержує приблизно 0,3-0,5 мг фтору на добу, то, відповідно, необхідно ввести в організм до 1 мг фтору [1]. 
При вмісті фтору в питній воді 0,1-0,3 мг/л рекомендується дитині у віці до 3 років призначати усередину 0,25 мг фтору, від 3 до 5 років 0,5 мг і старше 5 років - 1 мг. Прийом натрію фториду в таблетках варто починати 3 2-го року життя дитини і продовжувати до 13-15 років. Протипоказанням для їх прийому є вміст фтору в питній воді понад 0,8 мг/л. Таблетку рекомендується приймати щодня відразу після сніданку не менше 250 днів на рік (краще розжовувати, запиваючи водою). Не рекомендується одночасно приймати препарати, що містять Са. Прийом таблеток натрію фториду 2-3 рази на рік можна чергувати 3 прийомом вітафтору [4].

Вітафтор- комбінований препарат, що містить натрію фторид $\mathrm{i}$ комплекс вітамінів A, D2, C. Натрію фторид має протикаріозну дію, накопичується в кістках, зубах і хрящах. Вітамін С обмежує відкладення фтору в тканинах і тим самим запобігає інтоксикації ним. Вітамін А сприяє нормальному розвитку зубів і правильному формуванню кістяка. Вітамін D, регулює обмін фосфору і кальцію в організмі [2].

Вітафтор приймають внутрішньо під час їжі чи через 10-15 хв після їжі один раз на день. Дітям від 1 року до 6 років його призначають по 1/2 чайної ложки, з 7 до 14 років - по 1 чайній ложці щодня протягом 1 міс., після 2-тижневої перерви курс лікування повторюють. Повторні курси рекомендується проводити 4-6 разів на рік із перервою на літні місяці. Препарат протипоказаний при вмісті фтору в питній воді понад 1,5 мг/л і при явищах A- i D-гіпервітамінозів. Форма випуску у флаконах темного скла по 100 мл [2].

Актуальною проблемою для стоматологічної служби в Україні $\epsilon$ створення ефективних підходів до комунальної профілактики, регіональних програм профілактики стоматологічних хвороб, заснованих на використанні методів диверсифікації ризиків. Для створення програм необхідно здійснити системний аналіз факторів ризику формування i прогресування стоматологічних хвороб, ранжувати їх значимість (виділити фактори, маркери й індикатори), створити прогностичні моделі, систему індикаторів якості та синтезувати процедуру оцінки ефективності [3].

\section{Література:}

1. Безвушко Е.В. Стоматологічна захворюваність дітей, які проживають на різних за екологічним станом територіях, та обгрунтування диференційованої профілактики уражень твердих тканин зубів: автореф. дис. на здобуття наукового ступеня доктора мед. наук: спец. «Стоматологія» // Е.В. Безвушко. К., 2013. 36 с. 
2. Бондаренко Я.С. Посібник для вивчення курсу «Фармакологія i фармакокінетика» // Д.: РВВ ДНУ, 2014. 36 с.

3. Грецька О.В. Індивідуальні методи в системі комплексної профілактики карієсу. СтоматологИнфо. 2014. № 2-3. С. 28-29.

4. Ніжник Г.П. Фармацевтична хімія: Підручник. 2-е вид. К.: ВСВ «Медицина». 2015. 350 с.

5 Preparation, structure and properties of pyridinium and bipyridinium hexafluoro silicates / V.O. Gelmboldt, E.V. Ganin, M.M. Botoshansky, V.Yu. Anisimov, O.V. Prodan, V.Ch. Kravtsov, M.S. Fonari // Journalof Fluorine Chemistry. 2014. V. 160, № 4. P. 57-63.

DOI https://doi.org/10.30525/978-9934-26-113-8-33

\title{
РОЗРОБКА ЕМУЛЬГЕЛЮ НА ОСНОВІ РОСЛИННОЇ СИРОВИНИ
}

\author{
Сліпченко Г. Д. \\ кандидат фармачевтичних наук, \\ дочент кафедри заводської технології ліків \\ Національний фармацевтичний університет \\ Рубан О. А. \\ доктор фармачевтичних наук, професор, \\ завідувач кафедри заводської технології ліків \\ Національний фармачевтичний університет \\ м. Харків, Украӥна
}

Проведено дослідження зі створення нового лікарського засобу (ЛЗ) для місцевого лікування ран на основі шоломниці байкальської екстракта сухого у формі емульгелю. Доцільність розробки даного ЛЗ було обгрунтовано за результатами маркетингового дослідження фармацевтичного ринку України дерматологічних препаратів 3 антимікробною, протизапальною і ранозагоювальною дією.

На основі проведених літературних досліджень нами були обрані гелеутворювальні речовини, які найчастіше використовуються при розробці засобів місцевої дії, а саме: карбомер марки «Ultrez $10 \mathrm{NF}$ », натрію альгінат та гідроксиетилцелюлоза (ГЕЦ) марки Natrosol 250 HНX. До отриманих гелів додавали як олійну фазу олію кукурудзяну в кількості $20 \%$ та емульгатор Prolipid $141^{\mathrm{TM}}$ у конценрації 3\%. 